$\mathrm{A} \int_{\cos } \mathrm{H}$

Article history :

Received : 29.11.2014

Revised : 29.03.2015

Accepted : 15.04.2015
Members of the Research Forum

Associated Authors:

${ }^{1}$ Department of Agricultural

Economics, Dr. B.S. Konkan Krishi

Vidyapeeth, Dapoli, RATNAGIRI

(M.S.) INDIA

Email : hodecon@rediffmail.com
Author for correspondence :

S.R. TORANE

Department of Agricultural

Economics, Dr. B.S. Konkan Krishi

Vidyapeeth, Dapoli, RATNAGIRI

(M.S.) INDIA
THEASIAN JOURNAL OF HORTICULTURE

Volume 10 | Issue 1 | June, 2015 | 64-70

Visit us -www.researchjournal.co.in

\title{
Technologies adoption, resource use and technical efficiency in Alphonso mango production
}

\section{A.A. SHINDE ${ }^{1}$, S.R. TORANE, J.M. TALATHI ${ }^{1}$ AND P.J. KSHIRSAGAR ${ }^{1}$}

ABSTRACT : The average adoption index of low, medium and high adopters group was 45.14 per cent, 64.73 per cent and 90.22 per cent, respectively. Whereas, at overall level it was 66.69 per cent. Among the different technologies, the adoption index was higher in application of nitrogen (98.42), organic manure (95.64) and use of Nutan mango harvester (88.33) whereas, it was low in use of Amar loranthus cutter (14.17) and measures for control of spongy tissue (17.50). The co-efficient of multiple determinations $\left(\mathrm{R}^{2}\right)$ indicated 96.20 per cent variation in mango production, explained by the independent variables included in the function. The ratio of MVP/MFC was more than unity in case of phosphorus, manures indicating the scope of expanding the use of these inputs. The expenditure on other variables i.e., human labour, nitrogen, potassium, insecticides and cultar need to be curtailed. Technical efficiency at overall level was 58.58 per cent. Among the groups such as low, medium and high adopters it was 59.29 per cent, 57.49 per cent and 62.80 per cent, respectively. Farmers having small land holding $(<$ 2.0 ha) area had technical efficiency 54.11 per cent. Large farmers, who hold area more than 4.0 ha, had technical efficiency 59.38 per cent and the medium farmers it was 56.56 per cent. The farm size and technical efficiency had exhibited positive relationship in mango production.

KEY WORDS : Technology adoption index, Resource use efficiency, Allocative efficiency, Technical efficiency

HOW TO CITE THIS ARTICLE : Shinde, A.A., Torane, S.R., Talathi, J.M. and Kshirsagar, P.J. (2015). Technologies adoption, resource use and technical efficiency in Alphonso mango production. Asian $J$. Hort., 10(1) : 64-70. 